\title{
Noritic rocks and associated nickel-copper-sulphide occurrences in Sukkertoppen district, central West Greenland
}

\section{K. Secher}

Field work in 1982 included detailed mapping and collection of samples of sulphide occurrences in the so called 'norite belt', Sukkertoppen district. Several nickel-copper-sulphide mineralisations related to norite rocks are known from the work of Kryolitselskabet Øresund A/S who mapped this rock suite and carried out exploratory investigations of the sulphides (Nielsen, 1976).

The earlier mapping has revealed a suite of metabasic plutonic rocks of mainly noritic composition which are situated in an arcuate belt, approximately $15 \times 75 \mathrm{~km}$, curving around the Finnefjeld gneiss complex east of Sukkertoppen (fig. 8). Metanorites are embedded in quartzo-feldspathic gneisses and rarely in amphibolitic rocks, and they occur as a series of irregular pods up to $6 \mathrm{~km}$ long within the arcuate belt.

The present investigation was carried out as part of GGU's mineral resources mapping and evaluation programme in central West Greenland, which this year focussed on the area covered by the 1:250000 map sheet 65 V.2. The field work was carried out in close cooperation with teams doing systematic reconnaissance geochemical stream-sediment and water sampling (to be discussed elsewhere), detailed soil geochemical investigation (Jensen \& Secher, this report) and experimental geophysical investigations (Thorning, this report).

The present work aimed at a general description of the structure and the metallogenetic behaviour of the known norite-related sulphide occurrences in order to reach an understanding of the mineral genesis within this section of the Archaean environment.

\section{Field observations}

The noritic rocks have a characteristic appearance with a weathered and disintegrated surface, and are covered in gravel with no vegetation. The norite bodies tend to form hills, and exfoliation commonly gives rise to oddly shaped cliffs.

Metanorite is a homogeneous, medium-grained, grey-green rock, composed of nearly equal portions of plagioclase and hypersthene and/or hornblende and biotite. Irregularly shaped masses locally show gradual transition into coarser grained, even pegmatitic leuconoritic and leucogabbroic rocks. Norites with orbicular texture are only found as drift boulders in the northern part of the area, although weathering often creates an orbicularlike texture in the norite.

Regional structures. The norite belt curves along the eastern border of the Finnefjeld gneiss complex (fig. 8, and Berthelsen, 1962). It is possible to regard the belt as interrupted and divided into a northern and southern part. The northern part is characterised by relatively few, large bodies, while the southern part consists of several small pods of norite. This division coincides approximately with the regional NE-SW trending faults dissecting some of the norite bodies. Remnants of Palaeozoic fossiliferous rocks are preserved in downfaulted blocks (Poulsen, 1966). Lamprophyric dykes related to the nearby Mesozoic Qaqarssuk carbonatite complex are also intruded along these faults (Larsen et al., in press). 
Fig. 8. Simplified map of the Sukkertoppen area (after Allaart, 1982, 1:500000 map). $X$ indicates the location of Sitdlisigssanguit nunât.

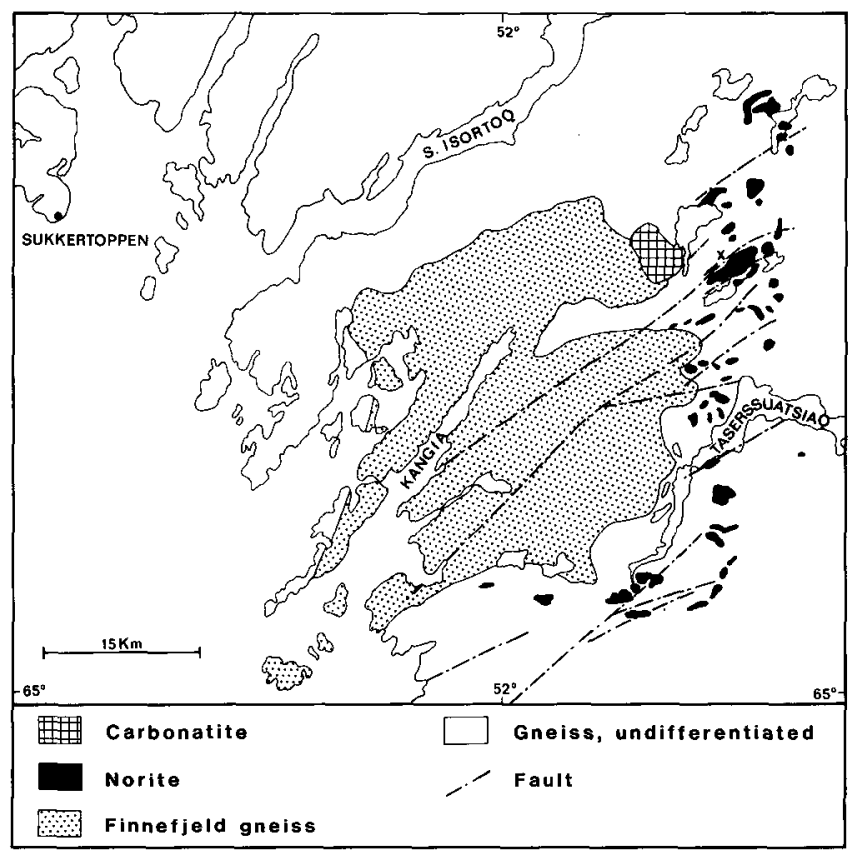

A group of such faults and shear zones reaching the coast south of Kangia is situated on the southern side of an elongated magnetic low (Thorning, 1976). This magnetic depression carries the northern section of the norite belt as well as the Qaqarssuk carbonatite complex, and suggests the presence of a deep-seated structure. This could have influenced the shape and/or number of norite pods by facilitating the intrusion of basic magma. Crustal activity guided by the same structural alignments occurred on several later occasions. These probably occurred in the Palaeozoic when fossiliferous sedimentary rocks were deposited and down-faulted and norites dissected, and later in the Mesozoic with the emplacement of carbonatite and lamprophyre. Thin carbonatite dykes, breccias and veins are also abundant in the surroundings and along the lineaments. Similar carbonatite veins together with kimberlite dykes are found as far south as the lake Taserssuatsiaq. However, the relationships between the Finnefjeld complex, the norite belt and the lineaments need detailed structural analysis and geochemical investigation to be further evaluated.

The deformation of the norite is very limited and only occurs on a local scale along contacts where foliation and sometimes agmatitic structures can be observed. Supposed primary igneous structures are undisturbed and only affected by recrystallisation during the regional metamorphism in granulite facies and retrogression in amphibolite facies (Allaart $e t$ al., 1978). However, the norite bodies are found to be concordant with the gneisses and amphibolites, which suggests a syn- to late tectonic emplacement.

Internal structures. Internal structures in the norites are of two main types; primary igneous structures and late to post-plutonic structures. Primary igneous structures are few in the extremely homogeneous rocks. They comprise xenoliths of gneiss along the contacts, and 


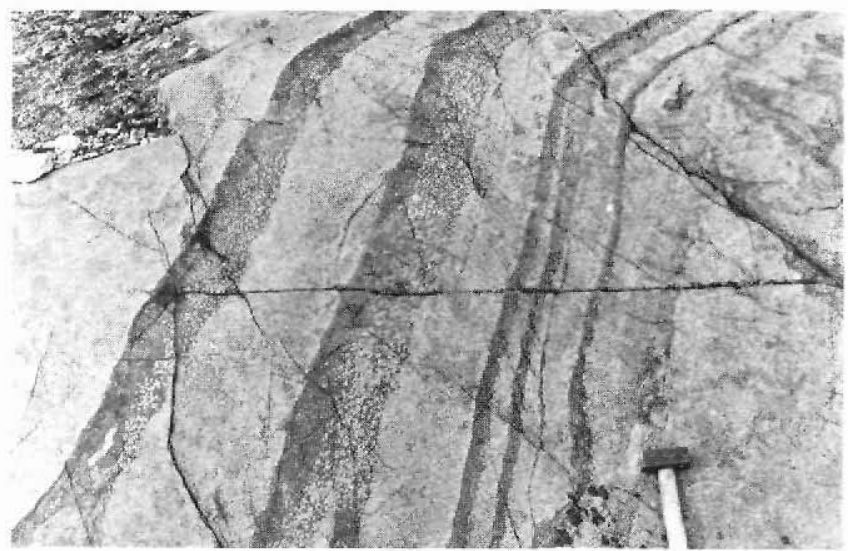

Fig. 9. Igneous banding in norite, Sitdlisigssanguit nunât.

structures interpreted as igneous banding (fig. 9). Late to post-plutonic structures include pegmatite and veins of acid to basic material, often with net-veining structure. Aplitic dykes of unknown composition are found sporadically. Pegmatitic dykes are observed in several phases, cutting each other and locally forming up to half of the rock volume, following a block-like fracturing structure. Some of these pegmatite dykes carry the blue quartz, ubiquitous in the granulite-facies metamorphosed rocks of the area. At least one generation of granitic pegmatites is of post-norite age. These, together with younger dolerite dykes, are found with the same strike as the previously mentioned regional lineaments.

\section{Sulphide occurrences}

The sulphide occurrences are scattered throughout the norite belt. The mineral content is very uniform, with pyrrhotite as the dominant ore mineral, and includes chalcopyrite, pyrite and magnetite which can be observed in hand specimens. Nielsen (1976) also reported pentlandite and bravoite as common constituents. Polished sections have not yet been examined in detail. Several types of sulphide accumulation are recognised such as disseminations, veinlets, interstitial infillings, and massive lumps of sulphides. The sulphide content varies from place to place up to a maximum of 25 per cent of the total rock volume.

The structural control of the mineralisation in the norite divides the sulphide occurrences into two major categories. They are either single spots or lensoid areas close to the contact, or groups of spots and/or lenses inside the norite bodies. The latter type is commonly aligned in a line following the dominant trend of shear zones and regional lineaments. This is the case around the 'Fossilik' norite body at Sitdlisigssanguit nunât where a piece of norite is apparently sliced off the main body and associated with several sulphide occurrences (Jensen \& Secher, this report). There is no observed relation between the size of the norite body and the intensity or number of sulphide occurrences. A general feature of the sulphide occurrences is their scattered, isolated nature in single spots or lenses, commonly not more than $5 \mathrm{~m}$ and rarely exceeding $25 \mathrm{~m}$ in length; they never extend into gneiss.

Characteristically the sulphides of the norite belt are strongly weathered, resulting in pronounced rust zones and even gossans with limonite, cuprite, malachite and azurite as the 
main alteration products. Covellite, chalcocite and native copper have also been reported as supergene products (Nielsen, 1976).

Ore minerals also related to the norite are apatite and magnetite, observed as coarse grains in one of the pegmatite phases. The quantity of these minerals is insignificant, although locally they reach very high concentrations. Norite showing probable igneous banding is at present being examined for chromite, ilmenite and platinum-carrying minerals. Platinum is reported from the sulphides (Nielsen, 1976).

\section{Discussion}

Field investigation within the norite belt confirms the existence of a very homogeneous noritic rock suite, and the evidence that primary igneous structures are well preserved establishes its low degree of deformation, in spite of its position in a severely deformed basement terrain. During regional deformation the norites have acted as resistant units, with fracturing as the only sign of deformation. The structural relationship between the Finnefjeld gneiss complex and the norite belt is speculative. The deep seated linear structure trending NE-SW, some ten kilometres wide, demonstrates probable influence on the development of major features of the area, by dividing the Finnefjeld complex and the norite belt curvature, dissecting the norites, hiding remnants of palaeozoic rocks and Mesozoic carbonatites. Additionally it is possible that the existence of this linear structure has supported necessary changes in part of the norite belt during emplacement, to create igneous banding in selected portions of the basic magma.

Igneous bands which have been observed at a few localities carry possible accumulation of chromite and platinum and are of primary magmatic origin. The sulphide occurrences are distributed within the norites in a heterogeneous manner and are genetically related to the magma. A high frequency of isolated sulphide occurrences close to igneous contacts may indicate a separation of sulphides in pockets from the norite magma early in the plutonic period. Later mobilisation might have influenced the distribution, taking advantage of synto late or even post-plutonic fracturing.

The economic potential of the $\mathrm{Ni}-\mathrm{Cu}$-sulphides is supposed to be medium to low due to their scattered occurrence, and no commercial exploration activity is going on at present. The possible presence of chromium and platinum in sections of the norite may increase its economic potential.

\section{References}

Allaart, J. H. (comp.) 1982: Geological map of Greenland 1:500000, sheet 2. Copenhagen: Geol. Surv. Greenland.

Allaart, J. H., Friend, C. R. L., Hall, R. P., Jensen, S. B. \& Roberts, I. W. N. 1978: Continued 1:500000 reconnaissance mapping in the Precambrian of the Sukkertoppen region, southern West Greenland. Rapp. Grønlands geol. Unders. 90, 50-54.

Berthelsen, A. 1962: Structural studies in the Pre-Cambrian of western Greenland. Meddr Grønland 123(2), $47 \mathrm{pp}$.

Larsen, L. M., Rex, D. C. \& Secher, K. in press: The age of carbonatites, kimberlites and lamprohyres from southern West Greenland: recurrent alkaline magmatism during 2500 million years. Lithos.

Nielsen, B. L. 1976: Economic minerals. In Escher, A. \& Watt, W. S. (edit.). Geology of Greenland, 460-487. Copenhagen: Geol. Surv. Greenland. 
Poulsen, V. 1966: An occurrence of Lower Palaeozoic rocks within the Precambrian terrain near Sukkertoppen. Rapp. Grønlands geol. Unders. 11, 26 only.

Thorning, L. 1976: Aeromagnetic surveys in southern and central West Greenland between $63^{\circ}$ and $71^{\circ}$ N. Rapp. Grønlands geol. Unders. 80, 61-65.

\section{A soil sampling programme near a sulphide mineralised norite body, Sitdlisigssanguit nunât, Sukkertoppen district, central West Greenland}

\section{Jensen and K. Secher}

A detailed geochemical soil sampling programme was carried out during the field season of 1982 on a known sulphide mineralisation. The aim of the programme is to evaluate soil sampling as a prospecting tool in arctic environments. Previous work by Kunzendorf \& Sørensen (1982) on the soil of the nearby Qaqarssuk carbonatite complex has shown promising results for selected elements. The programme also included the collection of rock samples from areas without soil cover. Bedrock is exposed over 5 per cent of the sampling area.

The survey was carried out as a part of GGU's resource evaluation programme in West Greenland (Secher, this report). It also forms part of the current investigation of geochemical methods in mineral exploration in Greenland. A total of 1059 soil samples were collected from two areas, both representing soil-covered contacts between bedrock gneiss and $\mathrm{Cu}-\mathrm{Ni}$ sulphide mineralised norite. In addition a total of 112 rock samples were collected. All samples collected during the programme will be analysed for relevant trace elements.

The sampled areas are situated about $65 \mathrm{~km}$ east of Sukkertoppen, central West Greenland, near the locality Sitdlisigssanguit nunât. The sulphide occurrence was found by the Kryolitselskabet Øresund, who named the locality 'Fossilik'.

The two soil sampling areas were covered with regular grids, constructed with the use of a theodolite and with a point density of $25 \mathrm{~m}$. Areas 1 and 2 are $450 \times 225 \mathrm{~m}$ and $112.5 \times$ $87.5 \mathrm{~m}$, respectively.

In Area 1 the slope varies; there are small ridges and hollows; and the altitude varies from $533 \mathrm{~m}$ to $593 \mathrm{~m}$. Area 2 is situated on a slope dipping $20^{\circ}-30^{\circ}$ to the south-east, with the altitude varying from $530 \mathrm{~m}$ to $572 \mathrm{~m}$.

\section{Geology of the sampling area}

The sampling area is located in Archaean terrain, and was selected to cover the contact zone of an intrusive norite mass in quartzo-feldspathic gneiss. The norite is part of a larger 